\title{
Alkene monooxygenase from Mycobacterium: a multicomponent enzyme
}

\author{
Sybe Hartmans, ${ }^{*}$ Frans J. Weber, Dianne P. M. Somhorst $\dagger$ and Jan A. M. De Bont \\ Division of Industrial Microbiology, Department of Food Science, Agricultural University Wageningen, PO Box 8129, \\ 6700 EV Wageningen, The Netherlands
}

(Received 24 April 1991; revised 16 July 1991; accepted 30 July 1991)

\begin{abstract}
A NADH- or NADPH-dependent alkene monooxygenase (AMO) activity has been detected in cell-free extracts of the ethene-utilizing Mycobacterium E3 and Mycobacterium aurum L1. The activity was not linear with protein concentration in the assay suggesting AMO is a multicomponent enzyme. The inhibition pattern of AMO activity was very similar to the inhibition patterns published for the three-component soluble methane monooxygenases. Fractionation of crude extracts revealed that combination of two fractions was required to restore alkene monooxygenase activity. The first fraction was inhibited by acetylene, indicating it contained an oxygenase component. The second fraction contained reductase activity which was absent from non-induced cells. This reductase activity is probably the NADH-acceptor reductase of AMO.
\end{abstract}

\section{Introduction}

Ethene-utilizing mycobacteria have been studied mainly in relation to the possibility of using them to produce optically active epoxides (Habets-Crützen et al., 1985; Weijers et al., 1988; Hartmans et al., 1989). Most studies have been done with whole cells and as yet little is known about the epoxidation reaction at the enzyme level. De Bont \& Harder (1978) demonstrated that the initial step in ethene metabolism in Mycobacterium E20 was the oxidation of ethene to epoxyethane by alkene monooxygenase (AMO). Low activities of AMO were also detected in crude extracts of Mycobacterium E20 (de Bont et al., 1979).

Oxidation of short-chain alkenes by methane monooxygenases also results in epoxide formation. Several methane monooxygenases have been studied in the past decade (Anthony, 1986). The most detailed studies have been done by H. Dalton and co-workers (see Anthony, 1986, for a review) with the soluble methane monooxygenase (MMO) of the type I methanotroph Methylococcus capsulatus (Bath). The MMO of Methylococcus capsulatus (Bath) has been resolved into three components that are all required for monooxygenase activity. Component $\mathrm{A}$ exhibits oxygenase activity in the pres-

$\dagger$ Present address: Agrotechnical Research Institute, PO Box 17, 6700 AA Wageningen, The Netherlands.

Abbreviations: AMO, alkene monooxygenase; MMO, methane monooxygenase. ence of components $C$ (reductase) and B (regulatory protein). In the absence of protein $B$, components $A$ and $\mathrm{C}$ exhibit 'NADH oxidase' activity, reducing oxygen to water at the expense of NADH (Anthony, 1986). From the facultative methane-utilizing Methylobacterium sp. strain CRL-26 a similar soluble MMO has been purified which did not require a regulatory type $B$ component (Patel \& Savas, 1987). Recently, it was shown that Methylosinus trichosporium OB3b, a type II methanotroph, also contains a three-component soluble MMO, very similar to the Methylococcus capsulatus (Bath) enzyme (Fox \& Lipscomb, 1988; Fox et al., 1989). Oxidation of alkenes to the corresponding epoxides by Pseudomonas oleovorans is also catalysed by a threecomponent monooxygenase, although this enzyme has no similarity to the soluble methane monooxygenases (May, 1979).

The methane- and alkane-utilizing bacteria oxidize a wide range of hydrocarbons (Colby et al., 1977; May, 1979; Stirling \& Dalton, 1979; Higgins et al., 1983; Witholt et al., 1990) due to the broad substrate specificity of the monooxygenases present. The alkene-utilizing bacteria generally only oxidize alkenes to the corresponding epoxides (van Ginkel et al., 1987). Based on this substrate specificity of AMO activity in whole cells the enzyme is expected to differ from reported monooxygenases.

This report describes the initial characterization of AMO from the ethene-utilizing Mycobacterium E3 (Habets-Crützen et al., 1984). 


\section{Methods}

Strains and cultivation. Mycobacterium E3 was isolated with ethene (Habets-Crützen et al., 1984) and Mycobacterium aurum Ll with vinyl chloride as carbon source (Hartmans et al., 1985). Production of biomass was by growth on ethene in a fed-batch manner in a 2 or 10 litre Applikon fermenter at $\mathrm{pH} 7$ and $30^{\circ} \mathrm{C}$. Ethene was supplied continuously as a $2 \%(\mathrm{v} / \mathrm{v})$ mixture in air at a rate of 0.2 v.v.m. About half of the fermentation liquid, containing approximately $3 \mathrm{~g}$ biomass (wet wt) $\mathrm{l}^{-1}$, was harvested daily. After harvesting, the volume which had been withdrawn from the fermenter was replaced with new mineral salts medium. If biomass was not harvested daily, mineral medium was supplied continuously at a rate of $0.02 \mathrm{~h}^{-1}$. The mineral salts medium contains, per litre of deionized water: $1.55 \mathrm{~g} \mathrm{~K}_{2} \mathrm{HPO}_{4}$,

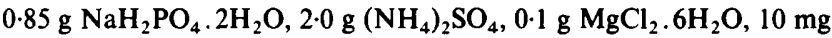
EDTA, $2 \mathrm{mg} \mathrm{ZnSO} \mathrm{Z}_{4} .7 \mathrm{H}_{2} \mathrm{O}, 1 \mathrm{mg} \mathrm{CaCl} 2.2 \mathrm{H}_{2} \mathrm{O}, 5 \mathrm{mg} \mathrm{FeSO}{ }_{4} .7 \mathrm{H}_{2} \mathrm{O}$, $0.2 \mathrm{mg} \mathrm{Na} \mathrm{MoO}_{4} .2 \mathrm{H}_{2} \mathrm{O}, 0.2 \mathrm{mg} \mathrm{CuSO}{ }_{4} .5 \mathrm{H}_{2} \mathrm{O}, 0.4 \mathrm{mg} \mathrm{CoCl}{ }_{2} .6 \mathrm{H}_{2} \mathrm{O}$ and $1 \mathrm{mg} \mathrm{MnCl} \cdot 2 \mathrm{H}_{2} \mathrm{O}$. Maintenance of strains, culture harvesting and storage of harvested cells were as previously described (Hartmans $\&$ de Bont, 1986).

Preparation of cell extracts. Crude cell extracts were prepared as described previously (Hartmans \& de Bont, 1986) except that $10 \%(\mathrm{v} / \mathrm{v})$ glycerol $(87 \%)$ was added before sonication. All chromatographic steps were done at $4{ }^{\circ} \mathrm{C}$. Dialysis of crude extracts was done overnight at $4{ }^{\circ} \mathrm{C}$ against 200 vols $50 \mathrm{~mm}$-potassium phosphate buffer, $\mathrm{pH} 7 \cdot 3$, with $8.7 \%$ glycerol (buffer A).

Fractionation on a DEAE-Sepharose CL-6B column $(25 \times 2.5 \mathrm{~cm})$. Elution was with a linear gradient of 0 to $1 \mathrm{M}-\mathrm{NaCl}$ in 1 litre of buffer $A$ at a fiow rate of $0.8 \mathrm{ml} \mathrm{min}{ }^{-1}$. Routinely about $0.5 \mathrm{~g}$ protein was applied to the column. The protein elution pattern was very reproducible, facilitating the localization of fractions $\mathrm{X}$ and $\mathrm{Y}$. Concentration of the pooled fractions (fraction $\mathrm{X}$ eluted at a $\mathrm{NaCl}$ concentration of about $220 \mathrm{~mm}$ and fraction $\mathrm{Y}$ eluted at about $300 \mathrm{~mm}-\mathrm{NaCl}$ ) from the DEAE-Sepharose column was done by ultrafiltration with an Amicon 8050 concentrator with Filtron membranes. The concentrated protein solution was subsequently diluted $(1: 10)$ with buffer $A$ and once again concentrated to remove most of the $\mathrm{NaCl}$.

\section{Enzyme assays}

All assays were done at $30^{\circ} \mathrm{C}$. Spectrophotometric assays were done on a Perkin-Elmer 550A spectrophotometer. Activities are expressed in nmol product formed $\min ^{-1}$ (mg protein) ${ }^{-1}$.

Alkene monooxygenase. This was assayed by analysing epoxypropane formation. Assays were done in serum bottles $(35 \mathrm{ml})$ sealed with a rubber septum. The reaction mixture contained $2 \mu \mathrm{mol} \mathrm{NADH}$, cell extract and buffer $A$ in a total volume of $1 \mathrm{ml}$. The serum bottles were incubated at $30^{\circ} \mathrm{C}$ in a reciprocating water-bath. After $2 \mathrm{~min}$ in the water-bath the reaction was started by the addition of $1 \mathrm{ml}$ propene via the rubber septum. Epoxypropane formation was determined by taking headspace samples every 2 to 3 min during a total incubation time of about $20 \mathrm{~min}$. Epoxypropane formation was linear during this time period. Inhibitors were tested by adding them to the assay mixture (incubated at $30^{\circ} \mathrm{C}$ ) $5 \mathrm{~min}$ before the reaction was started by the addition of propene. Extracts used in determining the $\mathrm{pH}$ optimum of AMO were prepared in demineralized water containing $0.85 \%(w / v)$ $\mathrm{NaCl}$ and $8.7 \%$ glycerol. Immediately after preparation, the extract was diluted 2-fold with the appropriate buffer ( $0.1 \mathrm{M}$-potassium phosphate for $\mathrm{pH} 7.0$ to 8.0 , and $0.1 \mathrm{M}$-Bis-Tris for $\mathrm{pH} 5.7$ to 7.0 ) and used to determine AMO activity.

$N A D(P) H$-acceptor reductase. These activities were assayed as described by Colby \& Dalton (1979) using potassium ferricyanide as artifical acceptor in buffer $\mathbf{A}$.
Component $X$. This was assayed either by adding acetyleneinactivated crude extract or fraction $Y$ to the assay. For both assays it was verified that component $\mathrm{X}$ was the rate-limiting component in the total assay mix.

Component $Y$. This was assayed by adding fraction $\mathrm{X}$ to the assay in amounts sufficient to ensure that component $Y$ was the rate-limiting component in the total assay mix.

Inactivation with acetylene. Inactivation of extracts was done by incubating extracts under the same conditions as were used for the AMO activity assay except that propene was omitted and $5 \%(\mathrm{v} / \mathrm{v})$ acetylene was added to the gas phase. After incubation for $30 \mathrm{~min}$ at $30^{\circ} \mathrm{C}$ the gas phase was flushed with air to remove all acetylene.

Slab gel electrophoresis. Flat polyacrylamide gels $(140 \times 80 \times 3 \mathrm{~mm})$ were prepared containing $7.7 \%(\mathrm{w} / \mathrm{v})$ polyacrylamide and $2.7 \%(\mathrm{w} / \mathrm{v})$ cross-linker in $100 \mathrm{~mm}$-phosphate buffer, $\mathrm{pH} 7 \cdot 3$. The vertical slab gels were run under non-denaturing conditions immersed in sodium phosphate buffer $(50 \mathrm{mM}, \mathrm{pH} 7.3)$ in a GE-2/4 gel electrophoresis apparatus from Pharmacia. Protein samples applied onto the gel contained $10 \%(\mathrm{w} / \mathrm{v})$ sucrose and $0.02 \%$ bromophenol blue. Electrophoresis was started at $200 \mathrm{~V}$ until the proteins entered the gel $(15$ to 20 $\mathrm{min}$ ) and was subsequently continued at $60 \mathrm{~V}$ until the dye reached the bottom of the gel. NADH-reductase activity staining was done immediately after electrophoresis by incubating the gel in $30 \mathrm{ml}$ of buffer $A$ with $1 \mathrm{~mm}-\mathrm{NADH}$ and $0.6 \mathrm{~mm}$-4-nitro blue tetrazolium chloride in the dark at $30^{\circ} \mathrm{C}$ for 30 to $60 \mathrm{~min}$.

Analytical methods. Protein was determined by the Bradford (1976) method using bovine serum albumin as standard. Epoxypropane was determined by analysing $200 \mu \mathrm{l}$ headspace samples on a Packard 430 gas chromatograph fitted with a stainless steel Porapak $\mathbf{R}$ column ( $100-$ $120 \mathrm{mesh}, 110 \mathrm{~cm} \times 1 / 8 \mathrm{in}$. i.d.) and a flame-ionization detector. The oven temperature was $180^{\circ} \mathrm{C}$ and the carrier gas $\mathrm{N}_{2}$ at $20 \mathrm{ml} \mathrm{min}^{-1}$.

Chemicals. Ethene, propene and carbon monoxide were from Hoek Loos (Schiedam, The Netherlands). Epoxypropane and glycerol (87\%) were from Merck. Acetylene was prepared from calcium carbide (Aldrich) as described by Burris (1974). NADH, NADPH and 4-nitro blue tetrazolium chloride were from Boehringer. $o$-Phenanthroline was from Janssen and 8-hydroxyquinoline was from Sigma. DEAESepharose CL-6B was from Pharmacia and membrane filters with a nominal cutoff of $10 \mathrm{kDa}$ (Omega NMWL 10K) were from Filtron Corporation.

\section{Results and Discussion}

\section{Determination of AMO activity}

AMO activity was assayed by determining epoxypropane formation from propene by headspace analysis. The rate of epoxypropane degradation by crude extracts is insignificant and using headspace analysis the formation of $2 \mathrm{nmol}$ epoxypropane could be detected. Cellfree extracts were routinely prepared in the presence of glycerol as this significantly enhanced the stability of AMO activity. Extracts of ethene-grown, but not glucose-grown cells of Mycobacterium strains E3 and L1 contained AMO activity. In both strains AMO activity was strictly dependent on $\mathrm{NAD}(\mathrm{P}) \mathrm{H}$ and oxygen. Extracts of Mycobacterium E3 contained slightly higher specific AMO activities than those from strain L1 and 


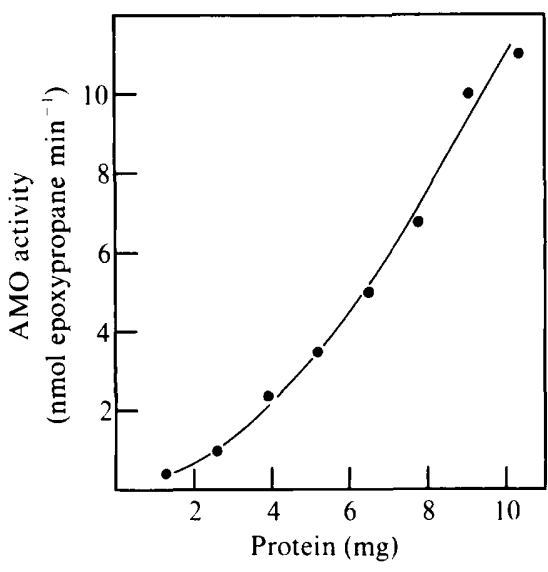

Fig. 1. Relationship between AMO activity and the amount of protein in the assay.

were consequently used in most experiments. The $\mathrm{pH}$ optimum for AMO activity was at $\mathrm{pH} 7.3$ to $7 \cdot 4$, with activities of about $10 \%$ of the maximum at $\mathrm{pH} 6.0$ and $\mathrm{pH} 8.0$. Ultracentrifugation of crude extract at $150000 \mathrm{~g}$ for $90 \mathrm{~min}$ resulted in complete recovery of activity in the supernatant indicating that AMO is a soluble enzyme. Elution of crude extracts over a G-10 Sephadex column resulted in significant loss of AMO activity, which could not be restored by the addition of the salt peak. Dialysis by dilution and subsequent concentration using a membrane with a $10 \mathrm{kDa}$ cutoff was, however, possible without significant loss of AMO activity.

$\mathrm{AMO}$, as with other soluble monooxygenases capable of oxidizing short-chain alkenes (Colby \& Dalton, 1976; Fox \& Lipscomb, 1988), probably consists of more than one component since activity as a function of the protein concentration in the assay mix gave a non-linear relationship (Fig. 1). From Fig. 1 specific activities up to $1 \cdot 1 \mathrm{nmol}$ epoxypropane $\min ^{-1}$ (mg protein) ${ }^{-1}$ can be calculated. This is significantly lower than the epoxypropane formation rate of $16 \mathrm{nmol} \mathrm{min}^{-1}(\mathrm{mg} \text { protein })^{-1}$ reported for whole cells of Mycobacterium E3 (HabetsCrützen et al., 1984). Preparation of extracts without glycerol gave initial specific activities which were about twofold higher.

The specific activities of AMO are also very low when compared with the specific activities of about $80 \mathrm{nmol}$ epoxypropane $\mathrm{min}^{-1}$ (mg protein) ${ }^{-1}$ reported for MMO from Methylococcus capsulatus (Bath) (Colby et al., 1977) and Methylosinus trichosporium OB3b (Fox \& Lipscomb, 1988).

\section{Inhibitors of AMO activity}

Using crude extracts several potential inhibitors of AMO activity were tested (Table 1). $o$-Phenanthroline,
Table 1. Inhibitors of alkene monooxygenase activity

Activity was determined by adding propene after $5 \mathrm{~min}$ preincubation at $30^{\circ} \mathrm{C}$ with inhibitor

\begin{tabular}{lcc}
\hline \hline \multicolumn{1}{c}{ Inhibitor } & Concn & $\begin{array}{c}\text { Inhibition } \\
(\%)\end{array}$ \\
\hline KCN & $1 \mathrm{mM}$ & 0 \\
& $5 \mathrm{mM}$ & 33 \\
o-Phenanthroline & $10 \mathrm{mM}$ & $>90$ \\
& $1 \mathrm{mM}$ & 23 \\
8-Hydroxyquinoline & $5 \mathrm{mM}$ & $100^{*}$ \\
Thiourea & $2 \mathrm{mM}$ & 53 \\
Allylthiourea & $10 \mathrm{mM}$ & 0 \\
NaN & $10 \mathrm{mM}$ & 0 \\
2,2'-Dipyridyl & $10 \mathrm{mM}$ & 0 \\
Salicylic acid & $10 \mathrm{mM}$ & 0 \\
EDTA & $10 \mathrm{mM}$ & 0 \\
Carbon monoxide & $10 \mathrm{mM}$ & 0 \\
Acetylene & $20 \%(\mathrm{v} / \mathrm{v})$ & $<5$ \\
\hline \hline
\end{tabular}

* Activity levelled off to zero during the assay.

8-hydroxyquinoline and potassium cyanide all significantly inhibited AMO activity. Other chelating agents tested did not result in significant inhibition, suggesting that any metal ion involved in alkene oxidation by AMO is well-shielded from attack by most metal-binding compounds. AMO activity, inhibited $40 \%$ with 2 mM-ophenanthroline, was restored completely by the addition of $2 \mathrm{mM}-\mathrm{Fe}^{2+}$, but not by adding $\mathrm{Cu}^{2+}, \mathrm{Zn}^{2+}, \mathrm{Mn}^{2+}$ or $\mathrm{Mg}^{2+}$, indicating that iron plays an essential role in AMO activity.

Carbon monoxide did not inhibit AMO, indicating that a P450 type of cytochrome is not involved. The strong inhibitory effect observed with acetylene has also been reported for several other monooxygenases (Hyman \& Wood, 1985; Hyman \& Arp, 1988; Prior \& Dalton, $1985)$. Inhibition by acetylene is dependent on the presence of both oxygen and NADH, and is a result of the transformation of acetylene by the monooxygenase to a reactive species which subsequently inactivates the active centre of the enzyme (Prior \& Dalton, 1985).

The observed inhibition pattern for AMO of Mycobacterium $\mathrm{E} 3$ is very similar to the inhibition patterns reported for the soluble methane monooxygenases of Methylococcus capsulatus (Bath) (Stirling \& Dalton, 1977) and Methylosinus trichosporium OB3b (Scott et al., 1981). Further characterization of the oxygenase component of the soluble MMO of M. capsulatus (Bath) (component A) revealed the presence of an unusual non-haem iron centre (Green \& Dalton, 1988). The iron in component A could be removed by dialysis against 8-hydroxyquinoline, resulting in an inactive protein. Reconstitution of the iron centre by incubating with iron-EDTA also resulted in reactivation of protein A (Green \& Dalton, 1988). 


\section{Separation of $A M O$ components}

AMO in crude extracts prepared without glycerol lost $50 \%$ of its activity after $5 \mathrm{~h}$ at $4{ }^{\circ} \mathrm{C}$. The crude enzyme preparation could be stabilized by adding glycerol. With $2 \cdot 6,4.4$ and $8.7 \%$ glycerol added to crude extracts, AMO activity half-life at $4{ }^{\circ} \mathrm{C}$ was extended to 9,18 and $40 \mathrm{~h}$ respectively.

In all subsequent experiments $8.7 \%$ glycerol was added to extracts and buffers. The addition of $\beta$ mercaptoethanol, PMSF, DTT, EDTA, NADH, $\mathrm{FeSO}_{4}$, $\mathrm{Fe}\left(\mathrm{NH}_{4}\right)_{2}\left(\mathrm{SO}_{4}\right)_{2} .6 \mathrm{H}_{2} \mathrm{O}$ as well as storage under anaerobic conditions did not affect the stability of AMO activity.

Separation of the individual components of AMO was attempted on a DEAE-Sepharose CL-6B column. Fractions pooled progressively to give $50 \mathrm{ml}$ pools were concentrated to assay AMO activity. No activity could be detected in any of these concentrated $50 \mathrm{ml}$ pools. Combination of all concentrated fractions, however, resulted in the recovery of some AMO activity. Apparently, the phenomena which resulted in the irreversible inactivation of AMO activity after elution over a G-10 Sephadex column played a less-significant role in DEAE column chromatography. The rate-limiting component of AMO activity was located by combining concentrated fractions from the DEAE-Sepharose CL-6B column with crude extract and assaying for increased AMO activities. The rate-limiting component, designated component $\mathrm{X}$, was located in the pooled fractions eluting between 545 and $615 \mathrm{ml}$ (Fig. 2). These pooled fractions did not exhibit any AMO activity without addition of crude extract. Using crude extract which had been stored for some time at $-20^{\circ} \mathrm{C}$ the increase in $\mathrm{AMO}$ activity upon addition of the fraction containing component $\mathrm{X}$ was even more significant: the activity of thawed crude extract containing $4.5 \mathrm{mg}$ protein increased from 0.8 nmol epoxypropane $\min ^{-1}$ to $10 \mathrm{nmol} \mathrm{min}{ }^{-1}$ when $7 \cdot 2$ $\mathrm{mg}$ protein of fraction $\mathrm{X}$ was added.

A preparation containing this presumably most labile component $\mathrm{X}$ of $\mathrm{AMO}$ was used to locate a second fraction which upon combination with fraction $X$ gave AMO activity. This second fraction was designated fraction $Y$.

At this stage it was verified that both components $\mathrm{X}$ and $\mathrm{Y}$ were present only in cells grown with ethene as growth substrate. Combination of fractions $X(2.2 \mathrm{mg}$ protein) or $Y(1.2 \mathrm{mg}$ protein) with crude extracts $(7.8 \mathrm{mg}$ protein) of glucose-grown cells did not result in detectable levels of AMO activity, indicating that components $\mathrm{X}$ and $\mathrm{Y}$ were indeed not present in extracts of glucosegrown cells. Furthermore, fractions containing components $\mathrm{X}$ and $\mathrm{Y}$ were also prepared from extracts of ethene-grown Mycobacterium aurum L1 cells. All combi- nations of fractions $\mathrm{X}$ and $\mathrm{Y}$ of the two strains resulted in activity, indicating a certain degree of similarity between the AMOs of the two strains.

\section{Characterization of fractions $X$ and $Y$}

In an initial characterization of fractions $\mathrm{X}$ and $\mathrm{Y}$ it was determined which of these fractions contained NADHacceptor reductase activity by following the reduction of the artificial acceptor potassium ferricyanide (Colby \& Dalton, 1979). Significant reductase activity was present in fraction $Y$. In a subsequent separation of fractions $X$ and $Y$ this assay was used to locate the reductase component $\mathrm{Y}$ more precisely (Fig. 2). Several peaks exhibiting reductase activity were located. Fractions from the peak with the highest reductase activity (670 to $730 \mathrm{ml}$ ) gave AMO activity upon combination with fraction $\mathrm{X}$ obtained by concentrating the protein peak which eluted between 545 and $615 \mathrm{ml}$. The location of fractions $\mathrm{X}$ and $\mathrm{Y}$ used in the activity determinations shown in Table 2 are depicted by the horizontal lines in Fig. 2.

As component $\mathrm{X}$ was assumed to be rate-limiting in crude extracts, the activity of crude extract can be assumed to be determined by the amount of component $X$ present. The specific activity of fraction $X$ in the presence of excess component $Y$ was $0.42 \mathrm{nmol} \mathrm{min}^{-1}$ $(\mathrm{mg} \text { protein })^{-1}$, which is only slightly higher than the specific activity of crude extract $\left[0.25 \mathrm{nmol} \mathrm{min}^{-1}(\mathrm{mg}\right.$ protein $\left.)^{-1}\right]$. The apparent purification of the reductase component $\mathrm{Y}$ appeared to be slightly higher, with the specific activity increasing from 0.41 to $1.99 \mathrm{nmol} \mathrm{min}^{-1}$ $(\mathrm{mg} \text { protein })^{-1}$ (Table 2). These low increases in specific activities could indicate that a third component is required for AMO activity, as has been established for the soluble MMOs (Anthony, 1986; Fox et al., 1989). If such a third component is required it is apparently present in limiting amounts in either fraction $\mathrm{X}$ or $\mathrm{Y}$ (or both). Attempts to further purify components $\mathrm{X}$ and $\mathrm{Y}$ should resolve this matter in the future.

Addition of fraction $\mathrm{X}$ to crude extracts which had been inactivated by incubation with acetylene restored AMO activity. As can be seen in Table 2 this gave the same specific activity $\left[0.45 \mathrm{nmol} \mathrm{min}{ }^{-1}(\mathrm{mg} \text { protein })^{-1}\right]$, based on fraction $\mathrm{X}$ protein, as the assay with excess

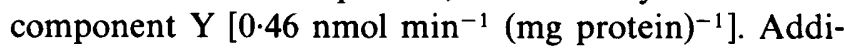
tion of fraction $Y$ to acetylene-inactivated extracts did not result in restoration of AMO activity. Apparently, inactivation with acetylene results in inactivation only of component $\mathrm{X}$. Inactivation of component $\mathrm{X}$ with acetylene is accomplished only in the presence of active AMO. Incubation of fractions $X$ and $Y$ separately with acetylene in the presence of NADH and oxygen for 30 min and subsequent removal of acetylene before combin- 


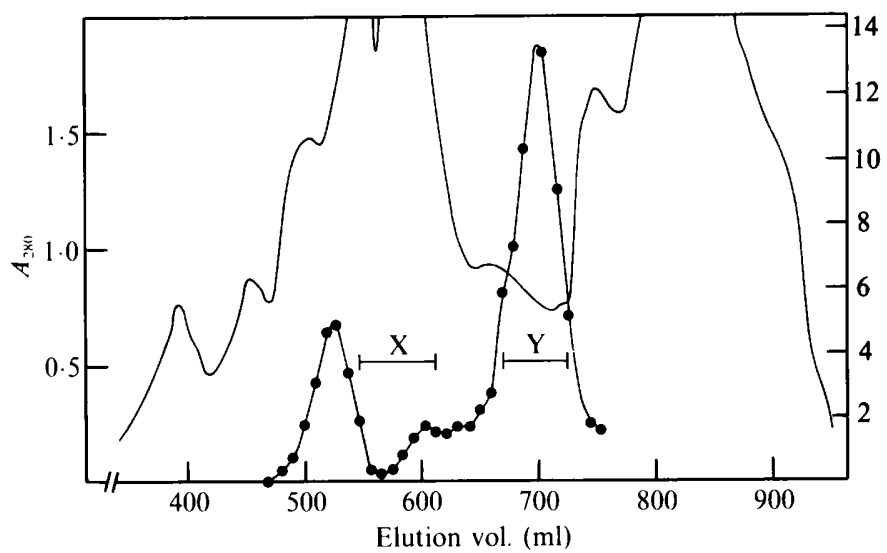

Table 2. Specific activities of alkene monooxygenase fractions

cfe, cell-free extract (stored at $4{ }^{\circ} \mathrm{C}$ during preparation of $\mathrm{X}$ and $\mathrm{Y})$; cfe/Ac, cell-free extract inactivated with acetylene; $\mathrm{X}$ and $\mathrm{Y}$, preparations fractionated on the DEAE column as depicted in Fig. 2.

\begin{tabular}{|c|c|c|c|c|c|c|}
\hline \multicolumn{4}{|c|}{$\begin{array}{l}\text { Protein in assay } \\
\text { (mg) }\end{array}$} & \multirow{2}{*}{$\begin{array}{c}\text { Activity } \\
\left(\text { nmol } \text { min }^{-1}\right)\end{array}$} & \multicolumn{2}{|c|}{$\begin{array}{l}\text { Specific activity } \\
{\left[\text { [nol min }{ }^{-1}\right.} \\
\left.(\mathrm{mg} \text { protein })^{-1}\right]\end{array}$} \\
\hline $\mathrm{cfe}$ & $\mathrm{cfe} / \mathrm{Ac}$ & $\mathrm{X}$ & $Y$ & & $X$ & $\mathrm{Y}$ \\
\hline 12.5 & - & - & - & $3 \cdot 1$ & 0.25 & - \\
\hline- & - & $1 \cdot 1$ & 1.9 & 0.46 & 0.42 & - \\
\hline 12.5 & - & $6 \cdot 0$ & - & $5 \cdot 0$ & - & 0.41 \\
\hline- & - & $7 \cdot 6$ & 0.62 & 1.23 & - & 1.99 \\
\hline- & 9.0 & $1 \cdot 1$ & - & 0.45 & 0.41 & - \\
\hline
\end{tabular}

ing both fractions gave active AMO. Combination of fractions $\mathrm{X}$ and $\mathrm{Y}$ before incubation with acetylene resulted in inactivation of AMO activity. These results indicated that both preparations are essential to produce the AMO-inactivating product of acetylene and that fraction $\mathrm{X}$ appears to contain the AMO component which can be inactivated by acetylene. Prior \& Dalton (1985) demonstrated that only one protein was labelled in soluble and particulate fractions of crude extracts of Methylococcus capsulatus (Bath) after incubation with $\left[{ }^{14} \mathrm{C}\right]$ acetylene. For the soluble MMO preparation the labelled polypeptide corresponded to the $\alpha$-subunit of component $\mathrm{A}$, the oxygenase component of the soluble MMO. By analogy with the soluble MMO of Methylococcus capsulatus (Bath), fraction $\mathrm{X}$ could very well contain the oxygenase component of AMO.

The specific activity of fraction $\mathrm{Y}$ when assayed with

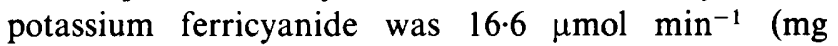
protein $)^{-1}$ compared to $230 \mu \mathrm{mol} \mathrm{min}^{-1}$ (mg protein) ${ }^{-1}$ reported for the purified component $\mathrm{C}$ of Methylococcus

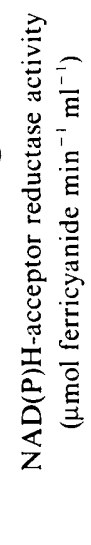

Fig. 2. DEAE-Sepharose CL-6B fractionation of crude extract. Fractions of vol. $8 \mathrm{ml}$ were collected. The horizontal lines indicate the elution volumes used to prepare fractions $\mathrm{X}$ and $\mathrm{Y}$. NAD $(\mathrm{P}) \mathrm{H}$ acceptor reductase activities $(O)$ were assayed with potassium ferricyanide as artificial acceptor.

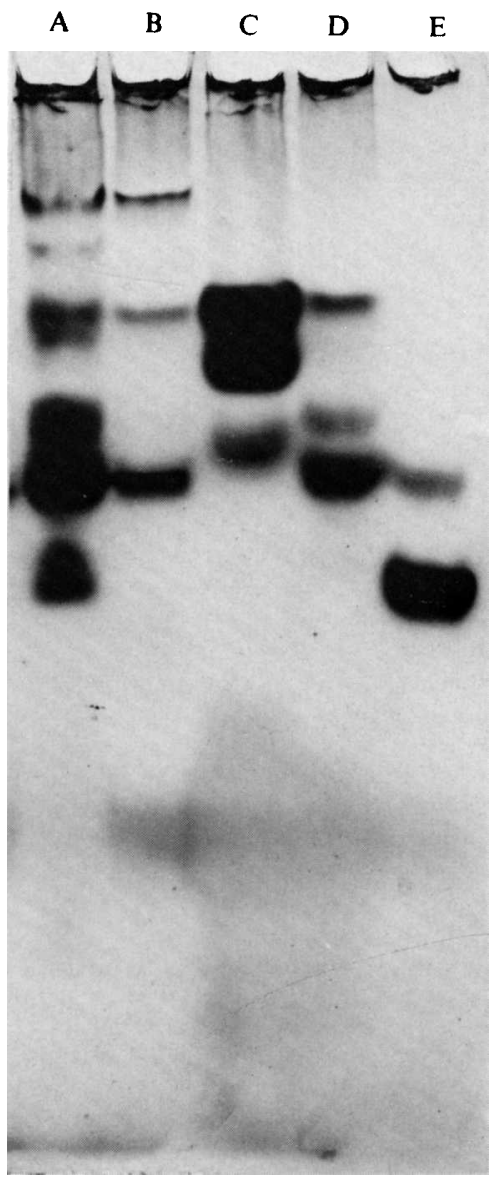

Fig. 3. Non-denaturing gel electrophoresis showing NADH reductase activity stained with 4-nitro blue tetrazolium chloride. Lane $A$, crude extract of ethene-grown cells; lane B, crude extract of glucose-grown cells; lane $C$, first peak with reductase activity from DEAE column (at $530 \mathrm{ml}$ ); lane $\mathrm{D}$, fraction $\mathrm{X}$; lane $\mathrm{E}$, fraction $\mathrm{Y}$.

capsulatus (Bath) (Colby \& Dalton, 1979). Using gel electrophoresis under non-denaturing conditions fraction $\mathrm{Y}$ was compared with several other samples after activity staining with 4-nitro blue tetrazolium chloride. 
As can be seen in Fig. 3 a band with reductase activity at the same migration distance as the major reductase component of fraction $\mathrm{Y}$ was present only in crude extracts of ethene-grown cells. Fraction $X$ and extracts of glucose-grown cells did not exhibit any detectable reductase activity at this migration distance. This indicates that the major band in the lane with fraction $Y$ is probably the reductase component of AMO.

It is therefore concluded that in both of the mycobacteria studied a multicomponent AMO is induced after growth on ethene. In extracts of Mycobacterium E3 two fractions (designated $X$ and $Y$ ) were located after separation on an anionic exchanger; upon combination these two fractions gave AMO activity. Based on inhibition experiments with acetylene it was concluded that fraction $\mathrm{X}$ contains an oxygenase component. Fraction $\mathrm{Y}$ contained significant reductase activity which is induced after growth with ethene. From the present data it is not clear if, in analogy with the soluble MMO, a third component is required for AMO activity. Attempts to further purify components $\mathrm{X}$ and $\mathrm{Y}$ should resolve this matter in the future.

\section{References}

Anthony, C. (1986). Bacterial oxidation of methane and methanol. Advances in Microbial Physiology 27, 113-210.

DE Bont, J. A. M. \& HARDER, W. (1978). Metabolism of ethylene by Mycobacterium E20. FEMS Microbiology Letters 3, 89-93.

de Bont, J. A. M., Attwood, M. M., Primrose, S. B. \& Harder, W. (1979). Epoxidation of short chain alkenes in Mycobacterium E20: the involvement of a specific mono-oxygenase. FEMS Microbiology Letters 6, 183-188.

BRADFORD, M. M. (1976). A rapid and sensitive method for the quantitation of microgram quantities of protein utilizing the principle of protein-dye binding. Analytical Biochemistry 72, 248-254.

BURRIS, R. H. (1974). Methodology. In The Biology of Nitrogen Fixation, p. 23. Edited by A. Quispel. Amsterdam: North Holland Publishing Co.

ColbY, J. \& Dalton, H. (1976). The soluble methane mono-oxygenase from Methylococcus capsulatus strain (Bath). Biochemical Journal 157, 495-497.

Colby, J. \& Dalton, H. (1979). Characterization of the second prosthetic group of the flavoenzyme NADH-acceptor reductase (component $\mathrm{C}$ ) of the methane mono-oxygenase from Methylococcus capsulatus (Bath). Biochemical Journal 177, 903-908.

Colby, J., Stirling, D. I. \& Dalton, H. (1977). The soluble methane mono-oxygenase of Methylococcus capsulatus (Bath). Biochemical Journal 165, 395-402.

Fox, B. G. \& LiPSCOMB, J. D. (1988). Purification of a high specific activity methane monooxygenase hydrolase component from a type
II methanotroph. Biochemical and Biophysical Research Communications 154, 165-170.

Fox, B. G., Froland, W. A., Dege, J. E. \& Lipscomb, J. D. (1989). Methane monooxygenase from Methylosinus trichosporium OB3b. Journal of Biological Chemistry 264, 10023-10033.

van Ginkel, C. G., Welten, H. G. J. \& DE Bont, J. A. M. (1987), Oxidation of gaseous and volatile hydrocarbons by selected alkeneutilizing bacteria. Applied and Environmental Microbiology 53, 2903-2907.

Green, J. \& Dalton, H. (1988). The biosynthesis and assembly of protein A of soluble methane monooxygenase of Methylococcus capsulatus (Bath). Journal of Biological Chemistry 263, 17561-17565.

Habets-Crützen, A. Q. H., Brink, L. E. S., van Ginkel, C. G., De Bont, J. A. M. \& Tramper, J. (1984). Production of epoxides from gaseous alkenes by resting-cell suspensions and immobilized cells of alkene-utilizing bacteria. Applied Microbiology and Biotechnology 20 , 245-250.

Habets-Crützen, A. Q. H., Carlier, S. J. N., de Bont, J. A. M., Wistuba, D., Schurig, V., Hartmans, S. \& Tramper, J. (1985). Stereospecific formation of 1,2-epoxypropane, 1,2-epoxybutane and 1-chloro-2,3-epoxypropane by alkene-utilizing bacteria. Enzyme and Microbial Technology 7, 17-21.

Hartmans, S., de Bont, J. A. M., Tramper, J. \& Luyben, K. CH. A. M. (1985). Bacterial degradation of vinyl chloride. Biotechnology Letters 7, 383-388.

HARTMANS, S. \& DE BONT, J. A. M. (1986). Acetol monooxygenase from Mycobacterium Pyl cleaves acetol into acetate and formaldehyde. FEMS Microbiology Letters 36, 155-158.

Hartmans, S., DE Bont, J. A. M. \& Harder, W. (1989). Microbial metabolism of short-chain unsaturated hydrocarbons. FEMS Microbiology Reviews 63, 235-264.

Higgins, I. J., Best, D. J. \& Hammond, R. C. (1983). New findings in methane-utilizing bacteria highlight their importance in the biosphere and their commercial potential. Nature, London 286, 561-564.

HYMAN, M. R. \& ARP, D. J. (1988). Acetylene inhibition of metalloenzymes. Analytical Biochemistry 173, 207-220.

HYMAN, M. R. \& WOOD, P. M. (1985). Suicidal inactivation and labelling of ammonia mono-oxygenase by acetylene. Biochemical Journal 227, 719-725.

MAY, S. W. (1979). Enzymatic epoxidation reactions. Enzyme and Microbial Technology 1, 15-22.

Patel, R. N. \& Savas, J. C. (1987). Purification and properties of the hydroxylase component of methane monooxygenase. Journal of Bacteriology 169, 2313-2317.

Prior, S. D. \& DALTON, H. (1985). Acetylene as a suicide substrate and active site probe for methane monooxygenase from Methylococcus capsulatus (Bath). FEMS Microbiology Letters 29, 105-109.

ScotT, D., Brannan, J. \& Higgins, I. J. (1981). The effect of growth conditions on intracytoplasmic membranes and methane monooxygenase activities in Methylosinus trichosporium OB3b. Journal of General Microbiology 125, 63-72.

Stirling, D. I. \& Dalton, H. (1977). Effect of metal-binding agents and other compounds on methane oxidation by two strains of Methylococcus capsulatus. Archives of Microbiology 114, 71-76.

WeiJers, C. A. G. M., van Ginkel, C. G. \& DE Bont, J. A. M. (1988). Enantiomeric composition of lower epoxyalkanes produced by methane-, alkane- and alkene-utilizing bacteria. Enzyme and Microbial Technology 10, 214-218.

Witholt, B., DE Smet, M.-J., Kingma, J., van Beilen, J. B., KoK, M., LAGEVEEN, R. G. \& EgGINK, G. (1990). Bioconversion of aliphatic compounds by Pseudomonas oleovorans in multiphase bioreactors: background and economic potential. Trends in Biotechnology 8, $46-52$. 